\title{
RESPONSE OF LETTUCE (LACTUCA SATIVA L.) TO SELENIUM IN NUTRIENT SOLUTION CONTAMINATED WITH NICKEL
}

\author{
Barbara HAWRYLAK, Renata MATRASZEK, Maria SZYMAŃSKA \\ Department of Plant Physiology, Agricultural University \\ Akademicka 15, 20-950 Lublin, Poland
}

Received: February 2, 2007; Accepted: August 10, 2007

\begin{abstract}
Summary
The influence of two selenium concentrations $(5$ and $20 \mu \mathrm{M})$ on crop yield, the content of chlorophyll, carotenoids and anthocyanins, as well as accumulation of nickel, selenium and sulphur were studied in the leaves of $50 \mu \mathrm{M}$ $\mathrm{Ni}$-stressed lettuce plants. Experiments were carried out in water cultures. The obtained results suggest that selenium at concentration of $5 \mu \mathrm{M}$ in nickel contaminated medium positively affected plants by stimulating their growth, increasing the concentration of assimilation pigments, and thereby at least partially prevented the toxic effect of nickel excess. Moreover, in plants enrichment with selenium a higher increase in content of chlorophyll $a$ than $b$ as well as a higher concentration of carotenoids were found. On the other hand, selenium affected a greater nickel uptake by lettuce plants.
\end{abstract}

key words: nickel phytoxicity, selenium, sulphur, lettuce

\section{INTRODUCTION}

Nickel is one of the more important metal pollutants contaminating the environment. Pollution of soils and waters with this element occurs mainly as a result of removing industrial and communal wastes, as well as irrational applying of the mineral fertilizers containing this metal (Déportes et al. 1995, Barcan \& Kovnatsky 1998). Plants growing in areas polluted with nickel easily accumulate it in their tissues. Dietary intake of nickel and other toxic elements through consumption of crop plants and long-term accumulation of pollutants in the organism can have an unfavourable effect on the health of people and animals (Boominathan \& Doran 2002).

Although nickel has been recognized as essential micronutrient in plant cells (Ankel-Fuchs \& Thauer 1988), it is however highly phytotoxic at high concentrations. Its excess has a destructive effect on plant growth, causing disturbances in photosynthesis, destruction of cell membranes and damages of cells at the ultrastructural level of their organization (Pandolfini et al. 1992,

Corresponding author:

e-mail: bhawrylak@yahoo.com

(c) Copyright by RIVC 
Moya et al. 1993, Boominathan \& Doran 2002). Being inactive in oxidoreductive changes, nickel does not directly generate free radicals, however, it indirectly induces oxidative stress, disturbing the equilibrium of the formation and destruction of active oxygen forms. This results from inactivation of proteins and also antioxidative enzymes by nickel, as well as from decreased pool of low-molecular antioxidants (Dietz et al. 1999).

It is suggested that one of the more important factors, through which heavy metals influence plant metabolism, is their interaction with the elements taken up as basic mineral components. The presence of heavy metals can induce deficiency of the elements necessary for proper plant development (BaranowskaMorek 2003). On the other hand, nickel uptake and its negative influence can be limited by some macronutrients, e.g. Fe or Ca (Matraszek 2001, 2003).

Selenium, approximate to sulphur as regards its chemical properties, so far has not been recognized as an essential element in nutrition of higher plants (Terry et al. 2000). Although selenium is toxic at high concentrations, recent studies have shown that it can positively influence on plants at low concentrations. The studies of Hartikainen et al. (2000) showed that selenium at low concentrations had antioxidative properties inhibiting peroxidation of lipids and enhancing the activity of glutathione peroxidase. Moreover, selenium can increase plant tolerance to oxidative stress induced by UV radiation (Hartikainen \& Xue 1999) and retard senescence of plants (Xue et al. 2001).

Taking into account the role of selenium in plant resistance to abiotic stresses, in the conducted experiments we attempted to limit nickel phytotoxicity through intensive nutrition of plants with this element.

\section{MATERIALS AND METHODS}

Experiments were carried out in a controlled climate room of the Plant Physiology Department, Agriculture University, Lublin, in the years 2005-2006. The study object was lettuce (Lactuca sativa L. var. capitata cv. Justyna).

The experiments were conducted by the method of water cultures in $1 \mathrm{~L}$ jars. At 4-true leaf phase, seedlings were transferred into 1.5-times concentrated Hoagland I solution ( $\mathrm{pH} 6.5$ ), supplemented by $2 \%$ ferric citrate solution $\left(2 \mathrm{~mL} \cdot \mathrm{L}^{-1}\right)$ and micronutrients in the form of $1 \% \mathrm{~A}-\mathrm{Z}$ solution $\left(3 \mathrm{~mL} \cdot \mathrm{L}^{-1}\right)$. After 2 -week plant growth the medium was differentiated in regard to the concentration of nickel $(0$ or $50 \mu \mathrm{M})$ and selenium $(0,5$ or $20 \mu \mathrm{M})$. Selenium was applied in the form of $\mathrm{Na}_{2} \mathrm{SeO}_{3} \cdot 5 \mathrm{H}_{2} \mathrm{O}$, whereas nickel in the form of $\mathrm{NiCl}_{2} \cdot 6 \mathrm{H}_{2} \mathrm{O}$. The experiments consisted of 12 series and 6 replications in each series. Constant thermal $\left(20 / 15^{\circ} \mathrm{C}\right.$, day/night) and light (photosynthetic photo flux density 203 $\mu \mathrm{mol} \cdot \mathrm{m}^{-2} \mathrm{~s}^{-1}$ ) conditions were maintained over the whole vegetation period. Plants were grown under a 14-h day length.

After 3 weeks of plant vegetation under differentiated experiment conditions, the yield of the fresh and dry weight of the edible parts was determined. In the fresh leaf weight the concentration of chlorophyll and carotenoids was determined by the method of Lichtenthaler \& Welburn (1983), and the content 
of anthocyanins by Harborne's technique in the modification of Martinez \& Favret (1990). The dry plant material was chemically analysed. The content of total sulphur and sulphur-sulphate was determined by the nephelometric method (Grzesiuk 1968, Ostrowska et al. 1991). The nickel content was determined by the method of atomic absorption spectroscopy (AAS), while that of selenium by the method of hydride generation atomic absorption spectroscopy (HGAAS).

The results are the means of the measurements made in two independent repetitions. The significance of differences between mean values were determined using Tukey's test. Differences at $\mathrm{P}<0.05$ were considered significant.

\section{RESULTS AND DISCUSSION}

Nickel applied at $50 \mu \mathrm{M}$ concentration to the nutritional solution of lettuce caused a considerable decrease of fresh weight $(41 \%)$ and dry weight $(28 \%)$ of the leaves (Table 1). As given by Gajewska et al. (2006), reduction of the plant weight may be partially connected with disturbances in water management and water content decrease in plant tissues. One of the nickel phytotoxicity symptoms observed in our studies was chlorosis and necrosis of old leaves. These symptoms occurred only occasionally on the newly developed leaves. This may indicate on nickel accumulation mainly in older leaves, which may function as metal sinks and therefore protect the developing leaves against toxic effect of nickel (Gajewska \& Skłodowska 2007).

In the leaves of lettuce growing in nickel contaminated medium, a considerable decrease of chlorophyll content, particularly of $a$, carotenoids and anthocyanins was found (Table 1). The results concerning chlorophyll content changes in the presence of toxic nickel concentrations are often contradictory. A relationship similar to that in our studies was shown by Pandey \& Sharma (2002) in nickel treated cabbage plants, but a reverse on by Gajewska et al. (2006), recording higher reduction of chlorophyll $b$ than $a$ in wheat plants. Comparing the content of pigments in the presence of heavy metals including nickel, in blue-green algae Nostoc muscorum the following tendency of their content decrease was found: chlorophyll $>$ phytocyanine $>$ carotenoids (Rai et al. 1990). Moreover, in nickel presence in nutrient solution a significant increase of nickel (Fig. 1A) and $\mathrm{S}^{-S}$ (Fig. 1D) content was found in lettuce leaves, whereas the content of total $\mathrm{S}$ did not change significantly (Fig. 1C). This probably accounts for disturbed sulphur metabolism in nickel treated plants. 
Table. 1. Influence of selenium on the yield and pigments content in leaves of lettuce grown under conditions of nickel contamination

\begin{tabular}{|c|c|c|c|c|c|c|c|}
\hline \multicolumn{2}{|c|}{$\begin{array}{l}\text { Element } \\
\text { concentra- } \\
\text { tion in nu- } \\
\text { trient solu- } \\
\text { tion }(\mu \mathrm{M}) \\
\end{array}$} & \multicolumn{2}{|c|}{$\begin{array}{l}\text { Weight of } \\
\text { aboveground } \\
\text { parts } \\
\text { (g) }\end{array}$} & \multicolumn{4}{|c|}{ Content of pigments $\left(\mathrm{mg} \cdot \mathrm{g}^{-1} \mathrm{FW}\right)$} \\
\hline $\mathrm{Ni}$ & $\mathrm{Se}$ & fresh & dry & $\begin{array}{c}\text { chlorophyll } \\
\text { a }\end{array}$ & $\begin{array}{c}\text { chlorophyll } \\
\text { b }\end{array}$ & carotenoids & anthocyanins \\
\hline 0 & 0 & $48.94 d$ & $2.708 \mathrm{~d}$ & $0.704 c$ & $0.287 \mathrm{c}$ & $0.681 \mathrm{~d}$ & $0.150 \mathrm{~b}$ \\
\hline 50 & & $28.84 \mathrm{a}$ & $1.948 \mathrm{a}$ & $0.215 \mathrm{a}$ & $0.146 \mathrm{a}$ & $0.214 \mathrm{a}$ & $0.100 \mathrm{a}$ \\
\hline 0 & & $44.62 \mathrm{c}$ & $2.465 \mathrm{c}$ & $0.944 \mathrm{e}$ & $0.346 \mathrm{~d}$ & $1.182 \mathrm{e}$ & $0.166 \mathrm{~b}$ \\
\hline 50 & 5 & $34.24 b$ & $2.122 \mathrm{~b}$ & $0.484 b$ & $0.172 b$ & $0.636 \mathrm{~d}$ & $0.275 \mathrm{c}$ \\
\hline 0 & & $36.26 \mathrm{~b}$ & $2.266 \mathrm{~b}$ & $0.678 \mathrm{c}$ & $0.265 \mathrm{c}$ & $0.348 \mathrm{c}$ & $0.170 \mathrm{~b}$ \\
\hline 50 & 20 & $25.12 \mathrm{a}$ & $1.808 \mathrm{a}$ & $0.199 \mathrm{a}$ & $0.124 \mathrm{a}$ & $0.284 b$ & $0.085 \mathrm{a}$ \\
\hline
\end{tabular}

Note: The means in each column marked by the same letters do not differ significantly at $\mathrm{P}=0.05$ using Tukey test.
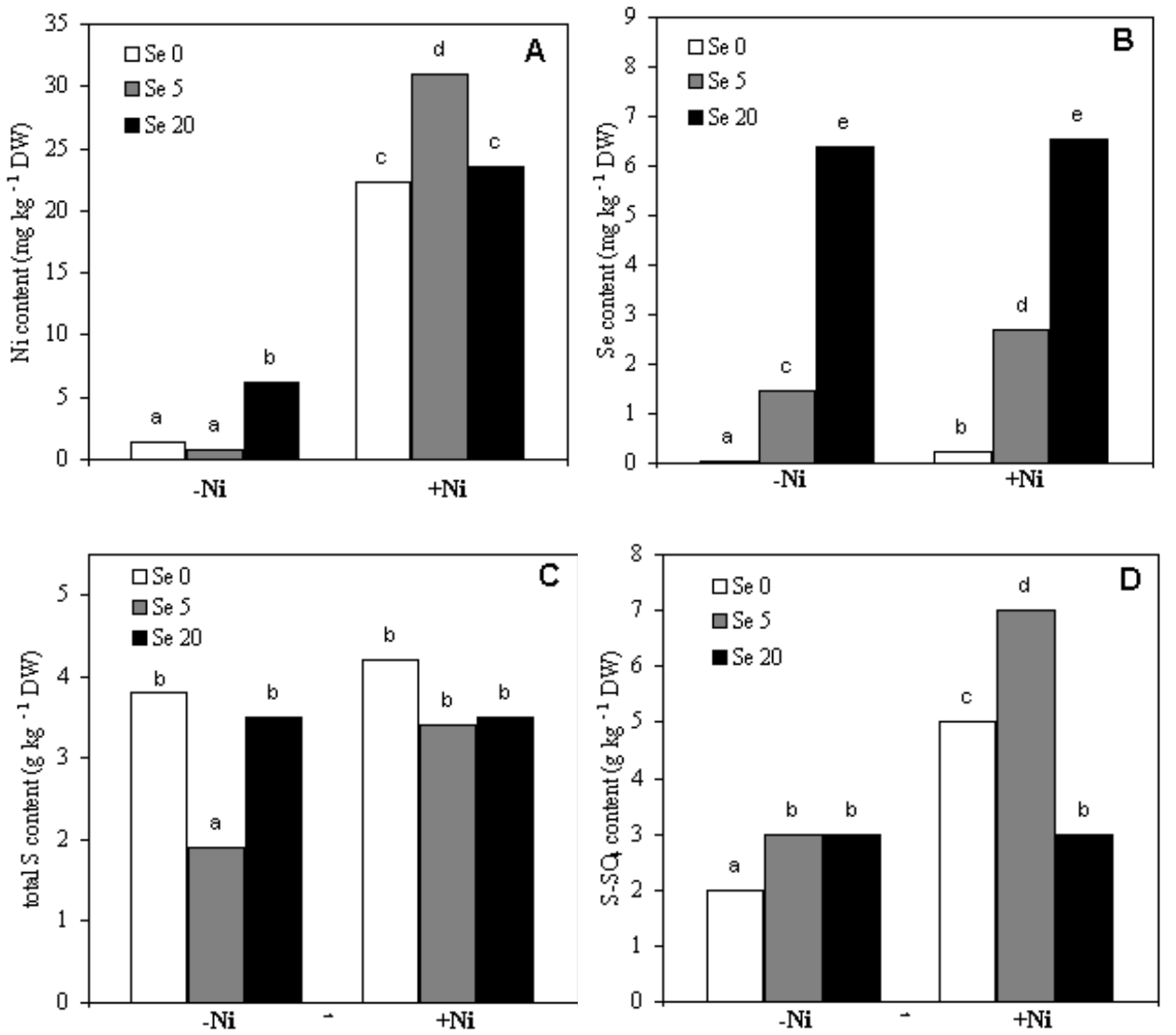

Fig. 1. Effect of selenium and nickel concentration on nickel (A), selenium (B), total sulphur (C) and sulphur-sulphate (D) content in lettuce leaves 
Selenium introduced into the medium not containing nickel induced 9 and $26 \%$ fresh weight decrease of the aboveground parts in the presence of 5 and 20 $\mu \mathrm{M}$ Se, respectively. The content of chlorophyll and carotenoids depends on the selenium dose. In the presence of $5 \mu \mathrm{M}$ Se the content of chlorophyll $a$ and $b$ was found to increase by $34 \%$ and $21 \%$, respectively, whereas in the medium containing $20 \mu \mathrm{M}$ Se a slight, statistically insignificant decrease of both chlorophyll forms was recorded (Table 1). The increase in chlorophyll content probably results from regulating role of selenium in the biosynthetic pathway of this pigment, especially as a result of its interaction with sulphydryl containing enzymes 5-aminolevulinic acid dehydratase and porphobilinogen deaminase (Padmaja et al. 1990). The content of carotenoids increased by $74 \%$ in the presence of $5 \mu \mathrm{M} \mathrm{Se}$, while the concentration increase to $20 \mu \mathrm{M}$ Se induced almost a $50 \%$ reduction in their content. No significant influence of selenium on the concentration of anthocyanins was found (Table 1). Moreover, regardless of the selenium concentration, medium enrichment with this element resulted in increased Se (Fig. 1B) and S-SO 4 (Fig 1D) content in the lettuce leaves. The content of total S has changed significantly only at $5 \mu \mathrm{M}$ Se (Fig 1C) where a $50 \%$ decrease of its concentration was shown. Selenium is generally assumed to affect the sulphur accumulation in plant tissues and vice versa (Severi 2001). The above antagonism occurs mainly between selenate and sulphate ions, what can be the consequence of the chemical similarity of both anions and of the similar, active mechanism of their uptake. However, the uptake of selenite form, which was used in our studies, is probably a passive process (Terry et al. 2000).

Enrichment of nickel polluted medium with $5 \mu \mathrm{M}$ Se significantly increased fresh (19\%) and dry (9\%) weight of the edible parts in comparison with the plants grown under nickel stress conditions. No statistically proved differences in yielding were shown in the presence of $20 \mu \mathrm{M}$ Se (Table 1). A bigger increase of fresh than dry weight may be connected with regulating role of selenium compounds in water management and tissue hydration increase (Hawrylak 2004). Selenium can stimulate a more effective water uptake through roots or limit transpiration intensity, and thereby reduce water loss from tissues (Kuznetsov et al. 2003).

After introducing $5 \mu \mathrm{M}$ Se into nickel polluted medium an increase of chlorophyll $a$ content by $125 \%$ and that of $b$ by $18 \%$ was observed. Selenium at $20 \mu \mathrm{M}$ concentration did not significantly affect the chlorophyll concentration. However, the both selenium doses $5 \mu \mathrm{M}$ and $20 \mu \mathrm{M}$ introduced into nickel containing nutrient solution caused about threefold and 33\% increase of carotenoids content, respectively. It should be stressed that after introducing $5 \mu \mathrm{M} \mathrm{Se}$ into the Ni-containing solution, the content of carotenoids in leaves reached the value similar to control treatment (Ni-0, Se-0). Similarly as in the case of carotenoids, the content of anthocyanins in plants grown in the presence of $5 \mu \mathrm{M} \mathrm{Se}$ increased significantly, reaching the level similar to control (Table 1). So far the effect of selenium on production and accumulation of low-molecular antioxidants, such as carotenoids and anthocyanins, has been little known. A tendency 
towards content increase of assimilation pigments and anthocyanins at low concentrations of different selenium compounds was shown by Hawrylak (2004).

The presence of selenium in the nickel containing medium effected increased Se concentration (Fig. 1B) in the leaf biomass, simultaneously de-

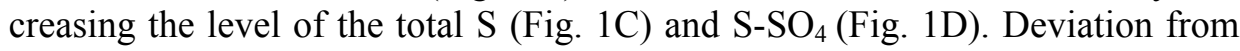
this rule was found at $5 \mu \mathrm{M}$ Se dose which caused increased sulphates content. Although in the presence of $5 \mu \mathrm{M}$ Se in the nickel polluted medium, improved yielding and increased assimilation pigments was recorded, nickel concentration in biomass was higher than in plants grown only under conditions of pollution with this metal (Fig. 1A). Thus it can be supposed that detoxifying effect of selenium on plants stressed by nickel was not connected with nickel uptake limited by selenium. It can be rather result from the beneficial effect of low selenium concentrations on the intracellular defence mechanisms that may support the integrity of metabolic processes under stress conditions. In animals selenium forms insoluble complexes with some heavy metals, what allows diminishing their unfavourable effect on metabolism (Rayman 2000). However, similar detoxification mechanism has not been found in plants yet.

\section{CONCLUSIONS}

1. Treatment of lettuce plants with $50 \mu \mathrm{M}$ Ni results in a great yield reduction and a significant decrease in content of assimilation pigments.

2. Enrichment of nickel polluted medium with selenium can partially reduce the toxic effect of nickel excess, which is accounted for by the increased yield as well as the higher content of photosynthetic pigments and anthocyanins. The more effective in diminishing nickel stress was selenium at 5 than $20 \mu \mathrm{M}$ concentration.

3. Selenium application to nickel polluted medium generally results in decrease of the total $\mathrm{S}$ and $\mathrm{S}_{-} \mathrm{SO}_{4}$ content in biomass of the leaves.

4. Increased selenium content $(5 \mu \mathrm{M})$ in nickel polluted medium has an effect on improved yielding and increased content of pigments, but it does not decrease this metal concentration in the biomass of the lettuce leaves.

\section{REFERENCES}

Ankel-Fuchs D., Thauer R.K. 1988. Nickel in biology: nickel as an essential trace element. pp: 93-110. In: The bioinorganic chemistry of nickel. (Lancaster J.R., ed.) Weinheim, Germany: VCH.

Baranowska-Morek A. 2003. [Mechanisms of plant tolerance to heavy metals.] Kosmos 52: 283-298. [in Polish with English summary]

Barcan V., Kovnatsky E. 1998. Soil surface geochemical anomaly around the coppernickel metallurgical smelter. Water, Air, and Soil Pollution 103: 197-218.

Boominathan R., Doran P.M. 2002. Ni-induced oxidative stress in roots of the Ni hyperaccumulator, Alyssum bertolonii. New Phytol. 156: 205-215.

Déportes I., Benoit-Guyod J.L., Zmirou D. 1995. Hazard to man and the environment posed by the use of urban waste compost: a review. Science of the Total Environment 172: 197-222. 
Dietz K.J., Baier M., Krämer U. 1999. Free radicals and reactive oxygen species as mediators of heavy metal toxicity in plants. pp: 73-97. In: Heavy metal stress in plants. (Prasad MNV, Hagemeyer J., eds.) Berlin, Germany, Springer.

Gajewska E., Skłodowska M. 2007. Effect of nickel on ROS content and antioxidative enzyme activities in wheat leaves. BioMetals 20: 27-36.

Gajewska E., Skłodowska M., Słaba M., Mazur J. 2006. Effect of nickel on antioxidative enzyme activities, proline and chlorophyll contents in wheat shoots. Biol. Plant. 50: 653-659.

Grzesiuk W. 1968. Nefelometryczne oznaczanie siarki siarczanowej w roślinach. Roczniki Gleboznawcze 19: 167-173. [in Polish]

Hartikainen H., Xue T. 1999. The promotive effect of selenium on plant growth as triggered by ultraviolet irradiation. J. Environ. Qual. 28: 1272-1275.

Hartikainen H., Xue T., Piironen V. 2000. Selenium as an anti-oxidant and pro-oxidant in ryegrass. Plant Soil. 225: 193-200.

Hawrylak B. 2004. Fizjologiczna aktywność różnych form selenu w roślinach determinowana $\mathrm{pH}$ środowiska odżywczego. Praca doktorska AR Lublin. [in Polish]

Kuznetsov Vas.V., Kholodova V.P., Kuznetsov V1.V., Yagodin B.A. 2003. Selenium regulates the water status of plants exposed to drought. Dokl. Biol. Sci. 390: 266-268.

Lichtenthaler H.K., Welburn A. 1983. Determination of total carotenoids and chlorophylls $a$ and $b$ of leaf extract in different solvents. Bioch. Soc. Trans. 603: 591-592.

Martinez A.E., Favret E.A. 1990. Anthocyanin synthesis and lengthening in the first leaf of barley isogenic lines. Plant. Sci. 71: 35-43.

Matraszek R. 2001. Wrażliwość roślin na nikiel w warunkach zróżnicowanej zawartości żelaza i wapnia w środowisku. Acta Agrobot. 54: 69-80. [in Polish]

Matraszek R. 2003. Changes of root physiological indices depending on $\mathrm{Ni}$ and $\mathrm{Ca}$ content in substrate. EJPAU 6(2). Available online: http://www.ejpau.media.pl/series/volume6/ issue2/horticulture/art-05.html

Moya J.L., Ros R., Picazo I. 1993. Influence of cadmium and nickel on growth, net photosynthesis and carbohydrate distribution in rice plants. Photosynth. Res. 36: 75-80.

Ostrowska, A., Gawliński S., Szczubiałka Z. 1991. Metody analizy i oceny właściwości gleb i roślin. Katalog Instytutu Ochrony Środowiska, Warszawa. pp. 334. [in Polish]

Padmaja K., Prasad D.D., Pradad A.R. 1990. Selenium as a novel regulator of porphyrin biosynthesis in germinating seedlings of mung bean (Phaseolus vulgaris). Biochem. Int. 22: 441-446.

Pandey N., Sharma C.P. 2002. Effect of heavy metals $\mathrm{Co}^{2+}, \mathrm{Ni}^{2+}$ and $\mathrm{Cd}^{2+}$ on growth and metabolism of cabbage. Plant Sci. 163: 753-758.

Pandolfini T., Gabbrielli R., Comparini C. 1992. Nickel toxicity and peroxidase activity in seedlings of Triticum aestivum L. Plant Cell Environ. 15: 719-725.

Rai L.C., Raizada M., Mallick N., Yashmin-Husaini A., Singh A.K., Dubey S.K. 1990. Effect of four heavy metals on the biology Nostoc muscorum. BioMetals 2: 229234.

Rayman M.P. 2000. The importance of selenium to human health. The Lancet 356: 233 241.

Severi A. 2001. Toxicity of selenium to Lemna minor in relation to sulfate concentration. Physiol. Plant. 113: 523-532.

Terry N., Zayed M., De Souza M.P., Tarun A.S. 2000. Selenium in higher plants. Annu. Rev. Plant Physiol. Plant Mol. Biol. 51: 401-432. 
Xue T., Hartikainen H., Piironen V. 2001. Antioxidative and growth-promoting effect of selenium in senescing lettuce. Plant Soil 237: 55-61.

\author{
REAKCJA SAŁATY (LACTUCA SATIVA L.) NA SELEN \\ W WARUNKACH SKAŻENIA ŚRODOWISKA NIKLEM
}

\title{
Streszczenie
}

Badano wpływ dwóch stężeń selenu (5 i $20 \mu \mathrm{M}$ ) na plonowanie, zawartość chlorofilu, karotenoidów i antocyjanów, jak również akumulację niklu, selenu i siarki w częściach użytkowych sałaty uprawianej w warunkach $50 \mu \mathrm{M}$ stresu niklowego. Doświadczenie przeprowadzono w kulturach wodnych. Uzyskane wyniki sugerują, że wzbogacenie środowiska skażonego niklem w $5 \mu \mathrm{M}$ selenu w wpływa pozytywnie na rośliny stymuluje ich wzrost, zwiększa koncentrację barwników asymilacyjnych i tym samym częściowo niweluje toksyczny wpływ niklu. Ponadto $\mathrm{w}$ roślinach wzbogaconych $\mathrm{w}$ selen wykazano większy wzrost zawartości chlorofilu $a$ niż chlorofilu $b$ oraz podwyższoną zawartość karotenoidów. Jednak z drugiej strony, selen wpływał na zwiększone pobieranie niklu przez rośliny sałaty. 